\title{
Challenges of Mining in the Brazilian Amazon
}

\author{
Silva EF* \\ Instituto de Geociências, Brazil
}

ISSN: 2578-0255

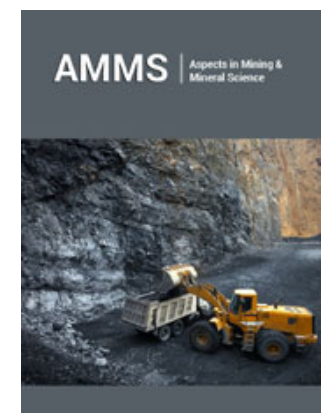

*Corresponding author: Silva EF, Master in Geology and geochemistry and consultant of geology and environmental projects by HG4 Environmental solutions and mining, Instituto de Geociências, Brazil

Submission: 侮July 27, 2019

Published: 侮 September 16, 2019

Volume 3 - Issue 3

How to cite this article: Silva EF. Improved Structural and Optical Properties Of C(Carbon)-Supported Zno Nanorod Arrays. Aspects Min Miner Sci.3(3). AMMS.000568.2019.

DOI: 10.31031/AMMS.2019.03.000568

Copyright@ Silva EF, This article is distributed under the terms of the Creative Commons Attribution 4.0 International License, which permits unrestricted use and redistribution provided that the original author and source are credited.

\section{Opinion}

The current environmental disasters caused by the mining sector in Brazil, Mariana and Brumadinho in Minas Gerais State, created a great concern on the practice of this activity in the Amazon. The Mining Industry in the Amazon is one of the most profitable industries in Brazil, e.g, for the Pará State the mining industry represented 4\% of the GDP-Gross Domestic Product-and generated 180,000 direct jobs. Nowadays, in the Amazon, the mining industry challenges are the absence of technologies capable of increasing exploitation and reducing hazards associated to this activity. Stated as region of expansion for the Brazilian Mining Sector, the mining industry in the Amazon generates concerns due to its territorial expansion that represents $60 \%$ of Brazil's continental area and due to conflicts caused by land usage. The biggest ventures of this industry were installed in the twentieth century in order to begin the exploration of diverse elements as: tin from the Pitinga mine (Amazonas State); bauxite from Trombetas, Paragominas and Juruti mines; iron, copper and nickel from Carajás mine; kaolin from Capim River basin (Pará State); manganese from Serra do Navio; and kaolin from Jari mine (Amapá State).

Comceptually, all material wasted during mining beneficiation are deposited in dams as its defined by NBR 13208/2017 law, which describes these places as "dams, buses, dikes, reservoir, depleted pits with built buses, whose construction is associated to activities that are developed based on mining rights and whose usage aims contention, accumulation, or decantation of mineral tailings or discharge of sediments from mining activities with or without water catchment, and whose extension is the dam and any structure associated to it". However, these containment techniques have been proven to be inefficient - according to the last events that occurred in the southeast region of Brazil. Supposing a disruption of any dam from the mentioned projects occurs, the effects would be catastrophic and irreversible, from the environmental point of view, for the Amazon biome. These effects would be noticed by the whole world population. Hence, it is necessary a greater investment in the mining industry modernization aiming another destination to mineral tailings. Nowadays, these tailings are deposited in basins and represent a potential danger for the environment and the population. Therefore, maintenance of the mining sector in the Amazon is limited to the employment of new technologies that can provide adequate destination to tailings resulting of mining beneficiation processes. 